Tersedia online di: http://ejournal-balitbang.kkp.go.id/index.php/bawal
e-mail:bawal.puslitbangkan@ gmail.com
BAWAL WIDYA RISET PERIKANAN TANGKAP
Volume 9 Nomor 2 Agustus 2017
p-ISSN: 1907-8226
e-ISSN: 2502-6410
BAWAL
Nomor Akreditasi: 620/AU2/P2MI-LIPI/03/2015

\title{
VARIASI GENETIKA IKAN BANYAR, Rastrelliger kanagurta (Cuvier, 1817) DI PERAIRAN INDONESIA TIMUR
}

\section{GENETIC VARIATION OF INDIAN MACKEREL, Rastrelliger kanagurta (Cuvier, 1817) IN THE WATERS OF EASTERN INDONESIA}

\author{
Achmad Zamroni, Suwarso dan Adi Kuswoyo \\ Balai Riset Perikanan Laut, Kompleks Raiser, J1. Raya Bogor KM. 47 Cibinong, Bogor \\ Teregistrasi I tanggal: 30 Mei 2017; Diterima setelah perbaikan tanggal: 15 Nopember 2017; \\ Disetujui terbit tanggal: 22 Nopember 2017
}

\begin{abstract}
ABSTRAK
Ikan banyar, Rastrelliger kanagurta (Cuvier, 1817) merupakan salah satu jenis ikan pelagis kecil bernilai ekonomis tinggi. Di perairan Indonesia bagian timur ikan ini mendominasi hasil tangkapan, terutama di sekitar Papua. Indikasi adanya penangkapan yang semakin intensif menyebabkan turunnya hasil tangkapan ikan banyar akibat turunnya kemampuan ikan untuk bereproduksi. Populasi yang berkurang dapat munurunkan variasi genetika yang ada. Untuk itu diperlukan suatu kajian variasi genetika ikan banyar. Penelitian ini menggunakan RAPD (Amplified Fragment Length Polymorphism) dengan lima primer. Sampel daging dari 24 ekor ikan dikumpulkan dari lima lokasi: Gorontalo, Kendari, Ambon, Raja Ampat dan Dobo. Hasil penelitian menunjukkan bahwa variasi genetika ikan banyar di Indonesia timur terdiri dari dua kelompok utama, kelompok pertama diwakili populasi Raja Ampat, Ambon, Kendari dan Gorontalo, kelompok kedua populasi dari Dobo.
\end{abstract}

Kata Kunci: RAPD; genetika; ikan banyar; Rastrelliger; Indonesia

\section{ABSTRACT}

Indian mackerel, Rastrelliger kanagurta (Cuvier, 1817) is an economic important small pelagic species. In the eastern part of Indonesia this species dominates the catch, especially surrounding of Papua Waters. Highly intensive catch activity alleges the catch down due to reducing the reproduction capasity and genetic variation. Therefore, a study of genetic variations of Indian mackerel fish in the waters of Eastern Indonesia is required. The research used RAPD (Amplified Fragment Length Polymorphism) with five primers. Twenty four sample of the muscle were collected from Gorontalo, Kendari, Ambon, Raja Ampat, and Dobo. The results showed that genetic variation consisted of two main groups. The first group consisted of Raja Ampat, Ambon, Kendari and Gorontalo populations, and the second group was the population from Dobo.

\section{Keywords: RAPD; Genetics; Mackerel; Rastrelliger; Indonesia}

\section{PENDAHULUAN}

Ikan banyar/kembung laki (Rastrelliger kanagurta) merupakan salahsatu ikan pelagis kecil yang masuk kedalam family Scombridae. Ikan ini bernilai ekonomis tinggi, umumnya dominan di perairan Indonesia bagian timur terutama di perairan barat Papua. Alat tangkap utama yang digunakan untuk menangkap ikan banyar adalah purse seine $(40,3 \%)$ dan gill net $(15,2 \%)$. Produksi mengalami penurunan, pada tahun 2013 tercatat sebesar 109.974 ton dan pada tahun 2015 menjadi 85.829 ton (DJPT, 2016). Penurunan produksi ini diduga karena eksploitasi ikan banyar sudah berlebih yang mengakibatkan Korespondensi penulis:

e-mail:ironzammiden@gmail.com

Telp. +6281210883373 menurunnya kemampuan ikan untuk bereproduksi. Selain berkurangnya produksi, turunnya reproduksi juga dapat mengurangi variasi genetika suatu spesies. Menurut Hughes et al. (2008) variasi genetika berdampak secara langsung atau tidak langsung terhadap keberlangsungan suatu populasi, komunitas dan ekosistem. Pemahaman tentang struktur populasi berguna untuk efektifitas manajemen sumberdaya (Nishida et al., 1998; Chiang et al., 2006; Chiang et al., 2008). Dalam populasi, variasi genetik adalah indikator untuk mengetahui kebugaran (fitness) suatu populasi, vasiasi genetik suatu populasi, dan dapat dideteksi dengan RAPD (Randomly Amplified Polymorphic DNA) (Kumari \& Thakur, 2014). 
Penelitian tentang struktur populasi dan variasi genetika ikan banyar di Indonesia belum dilakukan. Penelitian sebelumnya tentang variasi genetika ikan banyar di perairan Selat Malaka dan Laut Cina Selatan dengan menggunakan metode RAPD menunjukkan adanya perbedaan genetika (Zamroni et al., 2016). Beberapa penelitian pada ikan-ikan hasil penangkapan di laut, seperti ikan malalugis di Sulawesi (Zamroni et al., 2014), ikan layang (Suwarso \& Zamroni, 2014), ikan tuna sirip kuning di Laut Maluku (Akbar et al., 2014), ikan tongkol komo di Selat Malaka dan Laut Sulawesi (Santos et al., 2010), ikan cakalang di peairan Bali (Fakhri et al., 2015), ikan hiu (Carcharhinus sorrah) di perairan Jawa, Bali dan Lombok (Giles et al., 2014), ikan napoleon di perairan Jawa, Riau, Sulawesi Selatan, Nusa Tenggara Timur dan Nusa Tenggara Barat (Moria et al., 2006), ikan tongkol abu-abu di Pemangkat dan Pekalongan (Willette et al., 2016) dan ikan kembung perempuan (Rastrelliger barchysoma) di perairan Jawa (Indaryanto et al., 2015). Penelitian tentang genetika ikan banyar juga telah dilakukan di negara lain, diantaranya di India (Menezes et al., 1990; Menezes et al., 1993; Jayasankar et al., 2004; Sukumaran et al., 2017), Malaysia (Darlina et al., 2011; Akib et al., 2015), Thailand, Vietnam, Kamboja dan Madagaskar (Kielpinski et al., 2014), China (Chen et al., 2013), Thailand (Jondeung \& Karinthanyakit, 2015) Tujuan dari penelitian ini adalah untuk mengkaji variasi genetika ikan banyar (Rastrelliger kanagurta) di perairan Indonesia Timur, meliputi Gorontalo, Kendari, Ambon, Raja Ampat dan Dobo.

\section{BAHANDANMETODE \\ Lokasi Pengambilan Sampel}

Sampel ikan banyar (Rastrelliger kanagurta) diambil dari lima lokasi, yaitu Raja Ampat, Gorontalo, Kendari, Ambon dan Dobo (Gambar 1.). Tiap lokasi diambil 24 ekor ikan banyar secara acak yang diambil dagingnya untuk dianalisa DNA (Gambar 2.). Daging disimpan dalam etanol analis $96 \%$ sebelum dianalisis lebih lanjut di laboratorium.

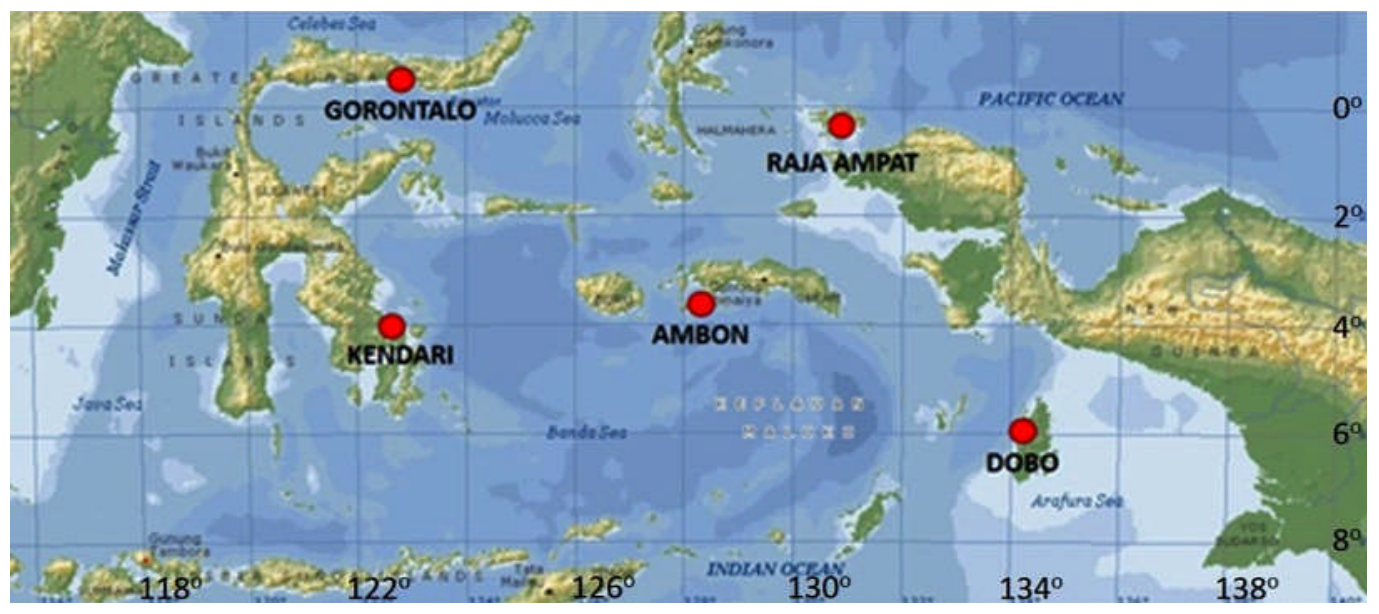

Gambar 1. Lokasi pengambilan sampel ikan banyar (Rastrelliger kanagurta).

Figure 1. Sampling sites of Indian mackerel (Rastrelliger kanagurta).

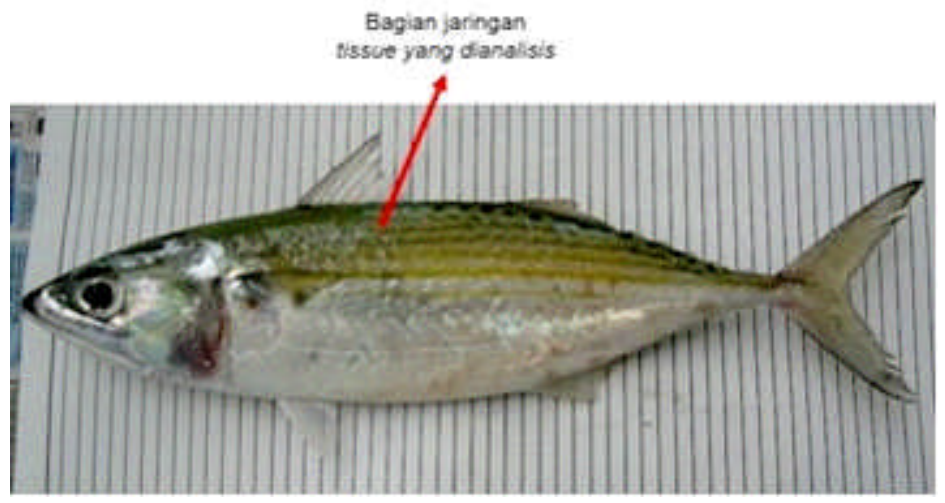

Gambar 2. Ikan banyar (Rastrelliger kanagurta) yang dianalisis dan posisi daging yang diambil. Figure2. The Indian mackerel (Rastrelliger kanagurta) and position of collected muscle. 


\section{Ekstraksi dan Amplifikasi}

Analisis RAPD menggunakan lima primer dilakukan di Laboratorium Genetika, Balai Penelitian Perikanan Laut, Jakarta. Ekstraksi DNA terhadap masing-masing sampel jaringan dilakukan dengan menggunakan metode spincolumn, kit ekstraksi yang digunakan dari Qiagen Dneasy Blood and Tissue Kit. Kit amplifikasi yang digunakan adalah Top Taq Mastermix Kit dari Qiagen. Profil siklus pada mesin PCR/thermal cycler adalah sebagai berikut: dilakukan initial heating $94^{\circ} \mathrm{C}$ selama 15 menit untuk mengaktifkan hot start DNA polymerase, dilanjutkan dengan 35 siklus pemanasan pada suhu $94^{\circ} \mathrm{C}$ selama 1 menit, $65^{\circ} \mathrm{C}$ selama 1 menit, $72^{\circ} \mathrm{C}$ selama 2 menit, dan diakhiri dengan suhu $72^{\circ} \mathrm{C}$ selama 5 menit.

\section{Analisis Data}

Hasil amplifikasi dari setiap primer terhadap masingmasing sampel (120 sampel) diperoleh tipe-tipe haplotype. Tipe-tipe haplotype dari masing-masing sampel kemudian dianalisis dengan software TFPGA (Tools for Population Genetic Analyses) (Miller, 1997), meliputi analisis keragaman haplotype (haplotype diversity), kekerabatan antar populasi melalui uji jarak berpasangan $\left(\mathrm{F}_{\mathrm{ST}}\right)$, jarak genetika dan hubungan kekerabatan antar populasi yang disajikan dalam bentuk dendrogram.

Analisis haplotype diversity dilakukan berdasarkan Nei \& Tajima (1981) dengan persamaan:

$\mathrm{h}=\frac{n}{n-1}\left(1-@ X_{i}^{2}\right)$

Keterangan:

$\mathrm{h}$ : haplotype diversity

$\mathrm{n}$ : jumlah sampel

$\mathrm{X}_{\mathrm{i}}$ : frekuensi haplotipe sampel ke i.

Analisis uji jarak berpasangan dilaksanakan untuk menduga perbedaan antara nukleotida-nukleotida (composite haplotype) antar populasi dengan cara menduga proporsi variasi total nukleotida (composite haplotype) yang tersebar di setiap populasi melalui persamaan sebagai berikut (Wright, 1951):

$\mathrm{F}_{\mathrm{ST}}=1-(\mathrm{Hw} / \mathrm{Hb})$

Keterangan:

$\mathrm{F}_{\mathrm{ST}}:$ indek diferensiasi

$\mathrm{Hw}$ : rata-rata perbedaan intra populasi

$\mathrm{Hb}$ : rata-rata perbedaan antar populasi

Jarak genetik merupakan ukuran perbedaan genetika antara populasi yang dihitung berdasarkan frekuensi haplotipe setiap populasi. Perhitungan jarak genetika berdasarkan Nei \& Tajima (1981) melalui program TFPGAdengan persamaan:

$\mathrm{D}=-\ln \left\{\mathrm{J}_{\mathrm{ab}} /\left\{\left(\mathrm{J}_{\mathrm{a}} \times \mathrm{J}_{\mathrm{b}}\right)^{0,5}\right\}\right]$

Keterangan:

D : jarak genetika

$\mathrm{J}_{\mathrm{ab}} \quad$ : frekuensi haplotipe pada lokus dengan populasi yang sama

$\mathrm{J}_{\mathrm{a}} \& \mathrm{~J}_{\mathrm{b}}$ : frekuensi haplotipe pada populasi A dan B.

Hubungan kekerabatan antar populasi dalam bentuk dendrogram berdasarkan analisis kluster terhadap nilai jarak genetika menurut metode jarak rata-rata UPGMA (Unweight Pair Group Methods Arithmatec) (Bermingham, 1990) dengan menggunakan software TFPGA(Miller, 1997).

\section{HASIL DAN BAHASAN Hasil}

Variasi situs/tipe hasil amplifikasi dari lima pasang primer yang digunakan diperoleh 11 (sebelas) tipe (allele), dengan 2 (dua) tipe A dan B dari primer III dan IV, 3 (tiga) tipe A, B dan C dari primer I, dan V, serta 4 (empat) tipe A, $\mathrm{B}, \mathrm{C}$ dan $\mathrm{D}$ dari primer II. Nilai variasi haplotipe yang diperoleh berkisar antar 0,3221 - 0,4205, populasi ikan banyar dari Gorontalo mempunyai nilai terendah sedangkan populasi dari Dobo mempunyai nilai variasi haplotipe tertinggi. Nilai variasi haplotipe rata-rata adalah 0,3586. Hasil penelitian ini menunjukkan bahwa semua populasi mempunyai nilai variasi haplotipe, artinya tidak ada populasi yang nilai keragaman haplotipe-nya 0 .

Tabel 1. Nilai keragaman haplotipe pada masing-masing lokasi pengambilan sampel ikan banyar

Table 1. Haplotype diversity of indian mackerel at five sampling sites

\begin{tabular}{llc}
\hline No & Lokasi Sampling (sampling location) & Haplotipe Diversity \\
\hline $\mathbf{1}$ & Raja Ampat & 0,3846 \\
$\mathbf{2}$ & Gorontalo & 0,3221 \\
$\mathbf{3}$ & Kendari & 0,2749 \\
$\mathbf{4}$ & Ambon & 0,4174 \\
$\mathbf{5}$ & Dobo & 0,4205 \\
\hline
\end{tabular}


Hasil analisis dengan menggunakan metode jarak berpasangan $\left(\mathrm{F}_{\mathrm{st}}\right)$ menunjukkan perbedaan genetika yang signifikan antara populasi ikan banyar dari Dobo dengan empat populasi lainnya (Raja Ampat, Gorontalo, Kendari dan Ambon). Populasi ikan banyar dari Ambon berbeda secara signifikan dengan populasi dari Kendari dan Gorontalo. Perbedaan signifikan juga terjadi antara populasi Kendar dan Gorontalo. Jarak genetika dengan menggunakan metode Nei (Nei \& Tajima, 1981) disertakan pada Tabel 3 .

Tabel 2. Hasil analisis antar populasi ikan banyarberdasarkan metode jarak berpasangan (Fst).

Table 2. Inter population analysis of indian mackerel with the pairwise distance ' $F_{S T}$ '.

\begin{tabular}{|c|c|c|c|c|c|}
\hline Lokasi (location) & Raja Ampat & Gorontalo & Kendari & Ambon & Dobo \\
\hline Raja Ampat & $* * * * *$ & & & & \\
\hline Gorontalo & $0,2095^{\mathrm{ns}}$ & $* * * * *$ & & & \\
\hline Kendari & $0,1744^{\mathrm{ns}}$ & $0,0052^{\mathrm{s}}$ & $* * * * *$ & & \\
\hline Ambon & $0,3938^{\mathrm{ns}}$ & $0,0005^{\mathrm{s}}$ & $0,0007^{\mathrm{s}}$ & $* * * * *$ & \\
\hline Dobo & $0,0004^{\mathrm{s}}$ & $0,0000^{\mathrm{s}}$ & $0,0000^{\mathrm{s}}$ & $0,0093^{\mathrm{s}}$ & $* * * * *$ \\
\hline
\end{tabular}

Keterangan/Remarks:

ns $\quad=$ tidak beda nyata $(\mathrm{P}>0,05)$;

$\mathrm{s} \quad \quad=$ beda nyata $(\mathrm{P}<0,05)$

$* * * * * \quad=$ kode untuk lokasi yang sama

Tabel 3. Jarak genetika antar populasi dari spesies ikan banyar (Rastrelliger kanagurta) berdasarkan metode Nei. Table 3. Nei's genetic distance of indian mackerel (Rastrelliger kanagurta)

\begin{tabular}{|c|c|c|c|c|c|}
\hline Lokasi (location) & Raja Ampat & Gorontalo & Kendari & Ambon & Dobo \\
\hline Raja Ampat & $* * * * *$ & & & & \\
\hline Gorontalo & 0,0108 & $* * * * *$ & & & \\
\hline Kendari & 0,0075 & 0,0321 & $* * * * *$ & & \\
\hline Ambon & 0,0105 & 0,0665 & 0,0488 & $* * * * *$ & \\
\hline Dobo & 0,0750 & 0,1343 & 0,1643 & 0,0788 & $* * * * *$ \\
\hline
\end{tabular}

Keterangan/Remarks:

$* * * * * \quad=$ kode untuk lokasi yang sama

(code for same location)

Dendrogram hubungan kekerabatan ikan banyar masing-masing perairan dengan menggunakan metode Reynolds et al. (1983) menunjukkan bahwa secara umum variasi genetika ikan banyar dibagi menjadi dua kelompok

populasi utama. Kelompok populasi pertama terdiri dari populasi Raja Ampat, Ambon, Kendari dan Gorontalo, sedangkan kelompok populasi kedua berasal dari populasi Dobo (Gambar 3).

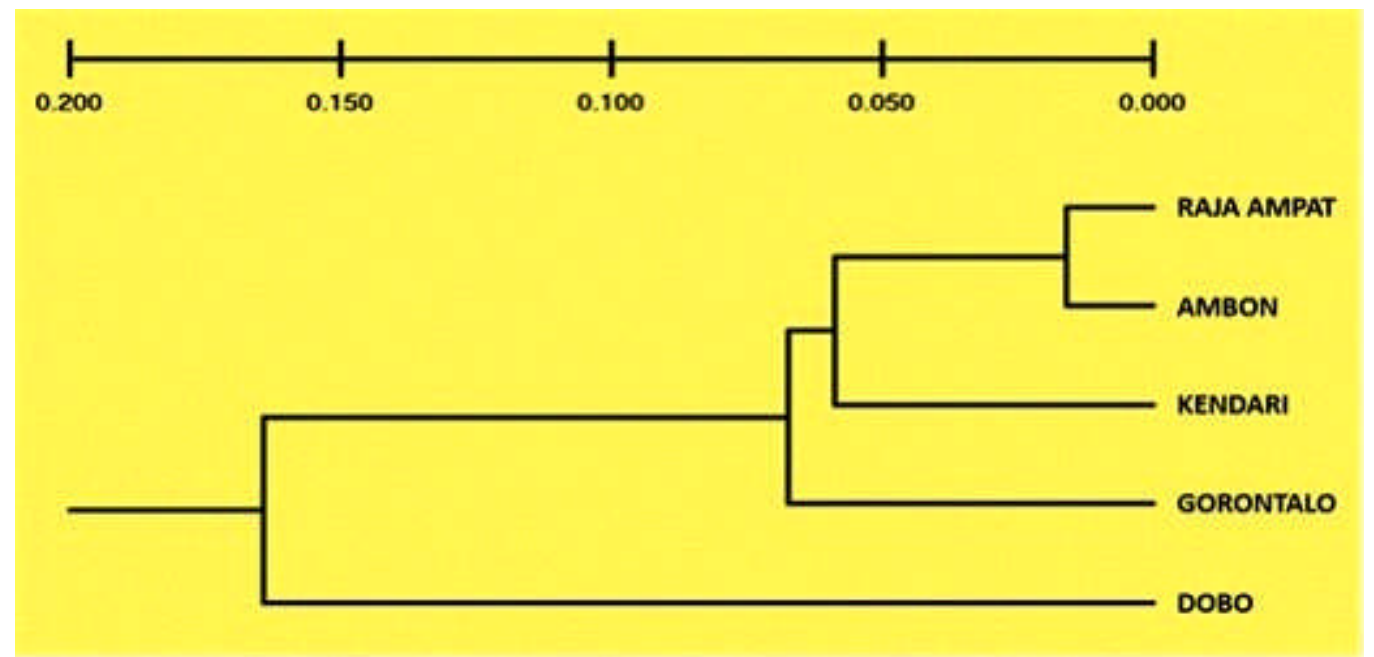

Gambar 3. Hubungan kekerabatan ikan banyar (Rastrelliger kanagurta) dari lima lokasi sampling.

Figure 3. Genetic relationship of indian mackerel (Rastrelliger kanagurta) from five sampling sites. 


\section{Bahasan}

Hasil penelitian menunjukkan bahwa terdapat dua kelompok utama pada struktur genetika populasi ikan banyar di perairan Indonesia Timur, kelompok populasi pertama berasal dari populasi Raja Ampat, Ambon, Kendari dan Gorontalo, sedangkan kelompok populasi kedua berasal dari populasi Dobo. Berdasarkan nilai jarak genetika menunjukkan bahwa antara populasi ikan banyar dari Gorontalo, Kendari, Ambon dan Raja Ampat mempunyai kekerabatan yang lebih dekat dibandingkan dengan populasi Dobo. Grafik dendrogram hubungan kekerabatan antar populasi juga menunjukkan bahwa populasi ikan banyar dari Gorontalo, Kendari, Ambon dan Raja Ampat terpisah dengan populasi Dobo. Hasil analisis jarak berpasangan F-st dan jarak genetika menurut Nei \& Tajima (1981) menunjukkan bahwa populasi ikan banyar dari Dobo berbeda sacara signifikan dengan empat populasi lainnya. Grafik dendrogram hubungan kekerabatan antar populasi juga menunjukkan bahwa populasi dari Dobo merupakan stok yang berbeda dengan empat populasi lain (Gambar

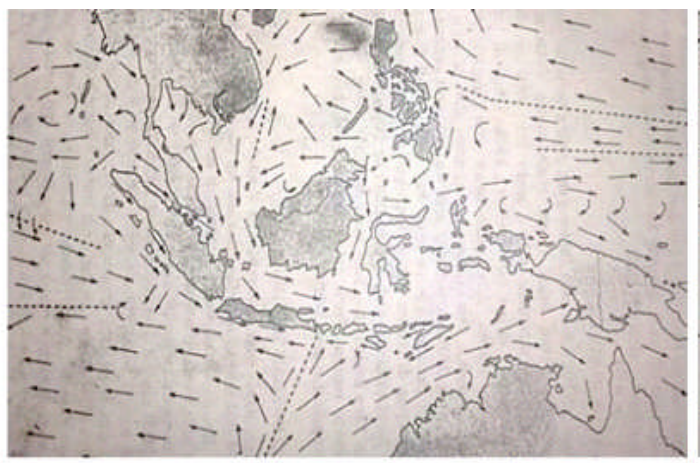

A
2.), sehingga dapat diduga bahwa populasi ikan banyar dari Dobo merupakan populasi/stok yang tersendiri. Hal ini didukung pula oleh lokasi perairan Dobo yang mempunyai posisi paling selatan (Laut Arafura) diantara empat lokasi populasi lainnya. Disamping itu, perairan Laut Arafura dipengaruhi oleh perairan dari Australia. Pola arus di Laut Arafura berdasarkan Wyrtki (1961) pada bulan Februari menunjukkan bahwa pergerakan arah arus berasal dari barat Australia menuju Laut Arafura dan bergerak menuju timur Australia (Gambar 4A), sedangkan pergerakan arus pada bulan Agustus menunjukkan pola yang sebaliknya (Gambar 4B).

Penelitian yang dilakukan oleh Daruwedho et al. (2016) mengenai pola arus di Indonesia juga menunjukkan pola arus yang sama dengan pola arus Wyrtki untuk perairan Laut Arafura (Gambar 5). Gaylord \& Gaines (2000) menjelaskan bahwa arus laut dapat mempengaruhi distribusi populasi, perubahan atau perbedaan karakteristik air yang dapat mempengaruhi fisiologi organisme untuk selanjutnya mempengaruhi struktur genetikanya.

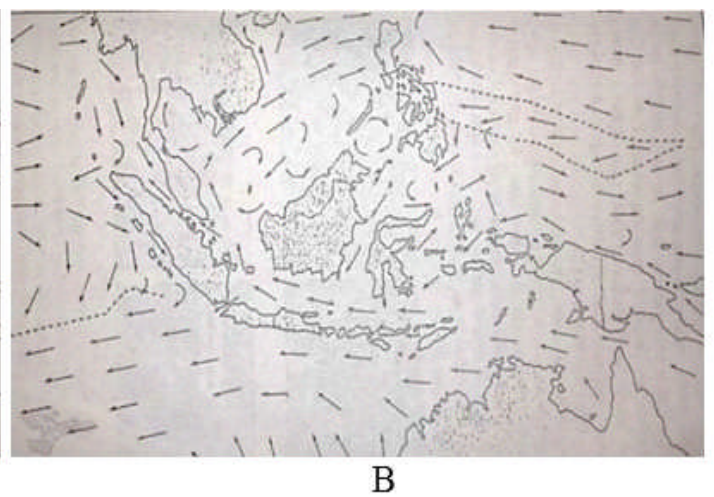

Gambar 4. Pola arus perairan Indonesia berdasarkan Wyrtki, A. Pola arus bulan Februari, B. Pola arus bulan Agustus (Wyrtki, 1961).

Figure 4. The current pattern of Indonesian waters by Wyrtki, A. Current pattern in February, B. Current pattern in August (Wyrtki, 1961).


Gambar 5. Model pola arus bulan Februari dan Agustus (Daruwedho et al., 2016).

Figure 5. Current pattern model in February and August (Daruwedho et al., 2016). 
Berdasarkan analisis $\mathrm{F}_{\mathrm{st}}$ dan nilai jarak genetika diketahui bahwa kekerabatan terdekat populasi ikan banyar dari Dobo adalah populasi ikan banyar dari Raja Ampat, karena kedua populasi tersebut (Dobo dan Raja Ampat) terdapat di sekitar perairan Papua. Nilai kekerabatan populasi Ambon sangat dekat dengan populasi Raja Ampat (paling dekat dibandingkan populasi lain), sehingga dapat dikatakan bahwa populasi Ambon dan Raja Ampat berasal dari stok yang sama. Diduga terjadi genetic drift (aliran gen) antara populasi Ambon dan Raja Ampat. Pola arus dari Samudera Pasifik menuju Laut Banda melalui perairan barat Papua mempermudah terjadinya genetic drift tersebut (Gambar 4 dan 5). Analisis $\mathrm{F}_{\text {st }}$ juga menunjukkan perbedaan yang signifikan antara populasi Ambon dengan populasi dari perairan di sekitar Sulawesi (Kendari dan Ambon). Perbedaan ini diduga karena pengaruh dari Arus lintas Indonesia (Arlindo) yang mengalir dari Samudera Pasifik ke
Samudera Hindia (Gambar 6). Rute Arlindo sebagaimana yang digambarkan Gordon \& Fine (1996) tidak melalui perairan sekitar Gorontalo dan Kendari, akan tetapi hanya melalui perairan sekitar Ambon (arus dari Pasifik Selatan). Arlindo yang berasal dari Pasifik Utara sebagian masuk ke Laut Maluku, akan tetapi berbalik arah menuju utara Halmahera, hal ini akan mempersulit terjadinya proses pencampuran populasi ikan dari Ambon dengan Gorontalo dan Kendari. Terjadinya perbedaan antara populasi Gorontalo dengan populasi Kendari diduga mempunyai sifat yang sama dengan hasil penelitian genetika ikan layang biru di perairan Sulawesi (Zamroni, et al., 2014). Hasil penelitian tersebut menunjukkan sedikit perbedaan antara populasi layang biru dari Gorontalo dengan perairan Bitung, Luwuk, Kendari dan Maumere, perbedaan tersebut diduga mengarah pada munculnya populasi lokal perairan Teluk Tomini.

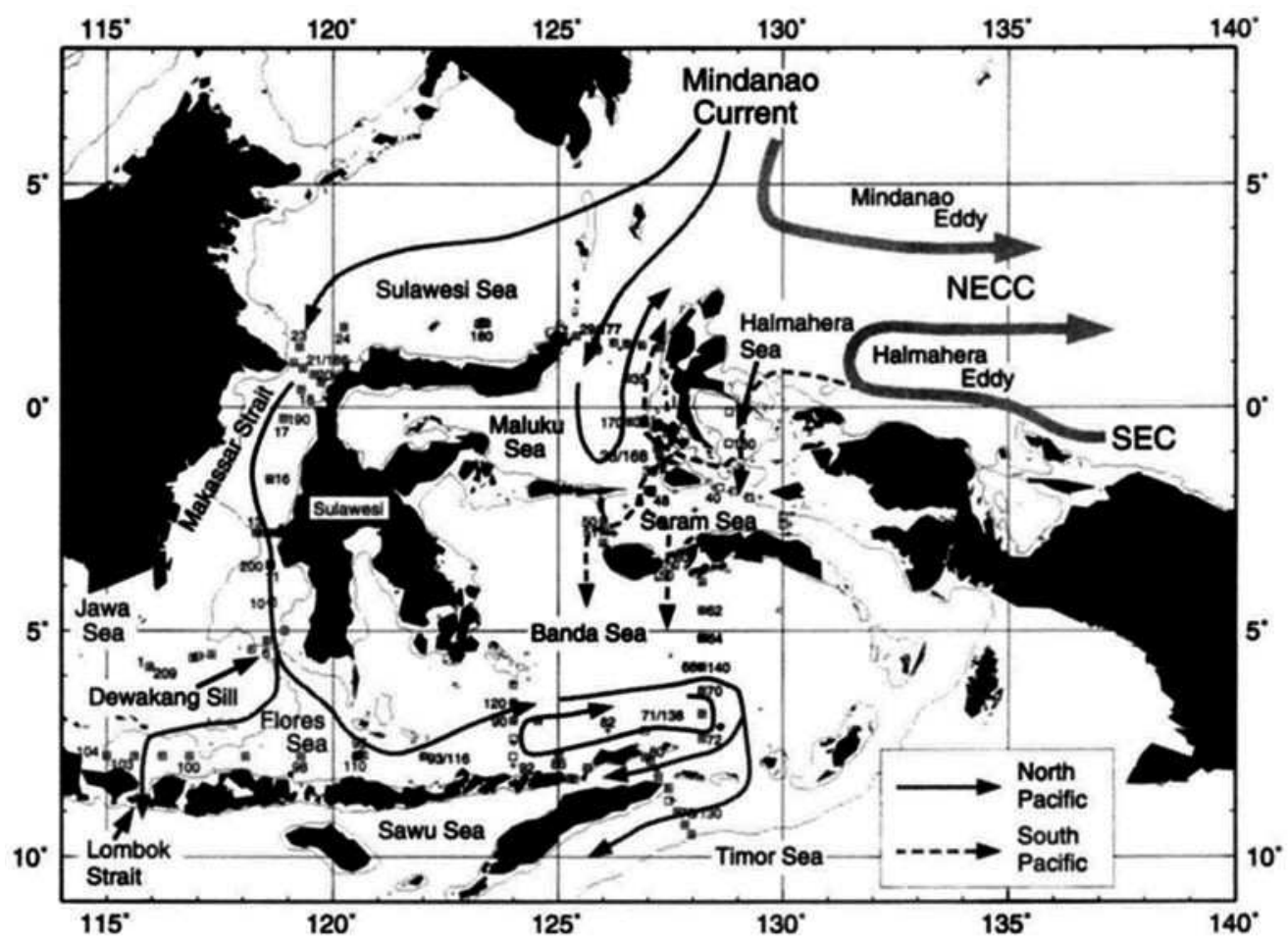

Gambar 6. Arus lintas Indonesia (Arlindo) (Gordon \& Fine, 1996).

Figure 6. Indonesian trhoughflow (Gordon \& Fine, 1996).

Nilai rata-rata keragaman genetika yang diperoleh dari lima populasi (lokasi sampel) adalah sebesar 0,3639. Nilai keragaman yang diperoleh ini lebih rendah dari kisaran seperti yang disebutkan oleh Tabata et al. (1997) bahwa keragaman haplotipe keseluruhan mtDNA untuk beberapa ikan berada dalam kisaran 0,473 - 0,998. Pada penelitian sebelumnya (tahun 2014) pada spesies yang sama di lokasi perairan Selat Malaka dan Laut Cina Selatan nilai keragaman genetika yang diperoleh lebih tinggi, yaitu 0,4816 (Zamroni et al., 2016). Nilai keragaman genetika yang tinggi terdapat pada populasi Dobo dan Ambon yaitu sebesar 0,4205 dan 0,4174 . Tingginya nilai keragaman genetika ikan Banyar populasi dari Dobo dan Ambon diduga karena migrasi yang lebih luas dibandingkan dengan tiga populasi lainnya. Sebagaimana diketahui bahwa Dobo masuk dalam perairan Laut Arafura yang sifatnya lebih terbuka dengan perairan lain sehingga spesies ikan pelagis pada perairan ini akan mudah bermigrasi. Begitu juga populasi yang berasal dari Ambon yang masuk dalam perairan Laut Banda bagian timur. Populasi di Raja Ampat dan Gorontalo mempunyai perairan yang lebih tertutup, sehingga kemampuan migrasi lebih rendah. Dengan melakukan migrasi kemungkinan ikan tersebut melakukan perkawinan acak antar populasi akan semakin besar. Adanya perkawinan acak ini akan 
menyebabkan pertukaran gen sehingga keragaman genetika akan tetap tinggi bahkan kemungkinan menjadi lebih tinggi. Ikan yang melakukan migrasi akan menutup kemungkinan terjadinya proses perkawinan sekerabat (inbreeding). Apabila inbreeding dibiarkan terjadi secara berulang-ulang maka peluang munculnya individu homozigot akan lebih tinggi dan menyebabkan keragaman genetika menjadi rendah. Suatu populasi yang mempunyai nilai keragaman genetika rendah akan menjadi rentan terhadap perubahan lingkungan dan serangan penyakit. Sebaliknya, populasi dengan nilai keragaman genetika yang tinggi mempunyai peluang hidup yang lebih baik untuk beradaptasi terhadap perubahan lingkungan (Hartl \& Jones, 1989).

Pada Tabel 1. dapat diketahui bahwa populasi di perairan sekitar Kendari mempunyai nilai keragaman genetika terendah diantara empat populasi lainnya. Diduga rendahnya nilai keragaman genetika tersebut karena adanya tekanan eksploitasi ikan Banyar yang intensif dan sudah berpengaruh terhadap keragaman genetika. Menurut Wilson \& Clarke (1996), eksploitasi yang semakin meningkat dan tekanan terhadap lingkungan dapat menyebabkan terjadi penurunan kelimpahan stok dan ratarata ukuran ikan; seleksi genetika yang merugikan terhadap fekunditas yang potensial; mengurangi rata-rata ukuran memijah; mengubah rasio jenis kelamin dan keseimbangan interspesifik; serta hilangnya diversitas genetika. Zein (2007) menyatakan bahwa, eksploitasi dapat menyebabkan peningkatan laju aliran gen (genetic drift), selain itu, populasi yang kecil cenderung akan terjadi kawin silang dalam (inbreeding), sehingga hal tersebut dapat berdampak buruk terhadap kelangsungan hidup dari populasi yang ada. Indikasinya adalah turunnya keragaman genetik dalam populasi, yaitu turunnya keragaman haplotipe dan keragaman nukleotida (Zein, 2007). Adanya penurunan variabilitas genetik ini dapat membahayakan kelangsungan hidup populasi karena dapat mengurangi kemampuan individual dalam menghadapi tekanan seleksi alamiah, terutama akibat perubahan lingkungan (Hedrick, 2000). Keanekaragaman dalam suatu spesies diperlukan untuk menjaga keanekaragaman antar spesies. Keanekaragaman genetik berperan sangat penting dalam sintasan dan adaptabilitas suatu spesies, karena ketika lingkungan suatu spesies berubah, variasi gen diperlukan agar spesies dapat bertahan hidup dan beradaptasi. Spesies yang memiliki keanekaragaman genetik tinggi pada populasinya akan memiliki lebih banyak variasi alel yang dapat diseleksi. Variasi genetika yang sedikit/kecil cenderung memiliki resiko lebih besar, seperti reproduksi yang kurang sehat dan keturunan yang lemah (tidak tahan terhadap tekanan).

Diketahui bahwa populasi ikan banyar dari Dobo berbeda dengan empat populasi lainnya (Gorontalo, Kendari, Ambon dan Raja Ampat), untuk itu dalam pengelolaan ikan banyar disarankan menggunakan pendekatan metode yang berbeda berdasarkan keragaman genetika pada masing-masing grup populasi utama. Grup populasi Gorontalo, Kendari, Ambon dan Raja Ampat cenderung mempunyai keragaman genetika yang rendah, sehingga untuk pengelolaan difokuskan terhadap peningkatan keragaman genetika dengan cara mengurangi tekanan penangkapan. Akibat dari penangkapan pada populasi ikan berpotensi terhadap terjadinya tiga perubahan genetika: mengubah struktur populasi, variasi genetika menjadi lebih rendah dan menghasilkan perubahan genetika yang selektif (Allendorf et al., 2008). Populasi ikan banyar dari Dobo pada penelitian ini mempunyai nilai keragaman genetika tertinggi. Keragaman genetika ini perlu dipertahankan misalnya dengan cara tidak dilakukan penambahan armada penangkap ikan atau dengan penerapan sasi/pelarangan penangkapan ikan pada musim tertentu terutama pada musim pemijahan.

\section{KESIMPULAN}

Variasi genetika ikan banyar (Rastrelliger kanagurta) di perairan Indonesia timur terdiri dari dua kelompok populasi. Populasi pertama berasal dari perairan Raja Ampat, Ambon, Kendari dan Gorontalo. Populasi ke dua berasal dari perairan Dobo. Kekerabatan terdekat terdapat pada populasi ikan banyar dari Raja Ampat dan Ambon. Nilai keragaman genetika populasi Gorontalo, Kendari, Ambon dan Raja Ampat cenderung lebih rendah. Disarankan untuk pengelolaan difokuskan pada pengurangan tekanan penangkapan, sedangkan pada populasi Dobo (keragaman genetika tinggi) difokuskan untuk mempertahankan keragaman genetika.

\section{PERSANTUNAN}

Kegiatan dari hasil penelitian Penelitian Stok, Distribusi dan Parameter Biologi Sumberdaya Ikan di WPP 714, WPP 715 dan WPP 718, TA 2015 di Balai Penelitian Perikanan Laut, Jakarta.

\section{DAFTAR PUSTAKA}

Akbar, N., Zamani, N. P., \& Madduppa, H. W. (2014). Keragaman genetik ikan tuna sirip kuning (Thunnus albacares) dari Dua Populasi di Laut Maluku, Indonesia. Depik, 3(1), 65-73.

Akib, N. A. M., Tam, B. M., Phumee, P., Abidin, M. Z., Tamadoni, S., Mather, P. B., \& Nor, S. A. M. (2015). High connectivity in Rastrelliger kanagurta: Influence of Historical Signatures and Migratory Behaviour Inferred from mtDNA Cytochrome b. PLoS ONE, 10(3).

Allendorf, F.W., England, P. R., Luikart, G., \& Ritchie, P. A. (2008). Genetic effects of harvest on wild animal populations. Trends in Ecol. Evol., 23, 327-337. 
Bermingham, E. (1990). Mitochondrial DNA and the Analysis of Fish Population Structure. In: D. H. Whitmore (ed.), Electrophoretic and Isoelectric Focusing Techniques in Fisheries Management (pp. 107-129). Florida, FL: CRC Press.

Chen, Y., Cheng, Q., Qiao, H., Zhu, Y., \& Chen, W. (2013). The complete mitochondrial genome sequence of Rastrelliger kanagurta (Perciformes: Scombridae). Mitochondrial DNA, 24(2). 114-116.

Chiang, H.C., Hsu, C. C., Lin, H.D., Ma, G.C., Chiang, T.Y., \& Yang, H.Y. (2006.) Population structure of bigeye tuna (Thunnus obesus) in the South China Sea, Philippine Sea and western Pacific Ocean inferred from mitochondrial DNA. Fisheries Research. 79, 219-22 5.

Chiang, H.C., Hsu, C.C., Wu, G.C.C., Chang, S.K., \& Yang, H.Y. (2008). Population structure of bigeye tuna (Thunnus obesus) in the Indian Ocean inferred from mitochondrial DNA. Fisheries Research. 90, 305-312.

Darlina, M. N., Masazurah, A. R., Jayasankar, P., Jamsari, A. F. J., \& Siti, A. M. N. (2011). Morphometric and molecular analysis of mackerel (Rastrelliger spp) from the west coast of Peninsular Malaysia. Genetics and Molecular Research, 10(3), 2078-2092.

Daruwedho, H., Sasmito, B., \& Fauzi, J. A. (2016). Analisis pola arus laut permukaan perairan Indonesia Menggunakan Satelit Altimetri Jason-2 Tahun 20102014. Jurnal Geodesi Undip, 5(2), 145-158.

DJPT. (2016). Statistik perikanan tangkap Indonesia, 2015.

Fakhri, F., Narayani, I., \& Mahardika, I. G. N. K. (2015). Keragaman genetik ikan cakalang (Katsuwonus pelamis) dari Kabupaten Jembrana dan Karangasem, Bali. Jurnal Biologi, 19(1).

Gaylord, B. \& Gaines, S. D. (2000). Temperature or transport? Range limits in marine species mediated solely by flow. American Naturalist, 155, 769-789.

Giles, J. L., Ovenden, J. R., Dharmadi, D., AlMojil, D., Garvilles, E., Khampetch, K., Manjebrayakath, H., \& Riginos, C. (2014). Extensive genetic population structure in the Indo-West Pacific spot-tail shark, Carcharhinus sorrah. Bulletin of Marine Science, 90(1). 427-454.

Gordon, A. L. \& Fine, R. A. (1996). Pathways of water between the Pacific and Indian oceans in the Indonesian seas. Nature, 379, 146-149.
Hartl, D. L. \& Jones, E. W. (1998). Genetics: principles and analysis (4th ed.). United State of America: Jones and Bartlett Publishers. Inc.

Hedrick, P. W. (2000). Genentics of populations ( $2^{\text {nd }}$ ed.). Sudbury: Jones and Bartlett Publishers.

Hughes, A. R., Inouye, B. D., Johnson, M. T. J., Underwood, N., \& Vellend, M. (2008). Ecological consequences of genetic diversity. Ecology Letters, $11,609-623$.

Indaryanto, F. R., Imai, H., \& Wardiatno, Y. (2015). Genetic variation of short body mackerel, Rastrelliger brachysoma of Jawa Island, Indonesia based on mtDNA control region sequences. AACL Bioflux, 8(5), 648-655.

Jayasankar, P., Thomas, P. C., Paulton, M. P., \& Mathew, J. (2004). Morphometric and genetic analyzes of indian mackerel (Rastrelliger kanagurta) from Peninsular India. Asian Fisheries Science, 17. 201-215.

Jondeung, A \& Karinthanyakit, W. (2015). Mitochondrial DNA control region of three mackerels, genus Rastrelliger: structure, molecular diversity and phylogenetic relationship. Mitochondrial DNA, Early Online. 1-6.

Kielpinski, M., Kempter, J., Panicz, R., \& Keszka, S. (2014). Genetic identifiability of selected populations of indian mackerel, Rastrelliger kanagurta (Actinopterygii: Perciformes: Scombridae) - Celfish Project - Part 1. Acta Ichthyol. Pascat, 44(2), 145-152.

Kumar, N. \& Thakur, S. K. (2014). Randomly amplified polymorphic DNA-A Brief Review. American Journal of Animal and Veterinary Sciences, 9(1), 6-13.

Menezes, M. R., Naik., S. \& Martins, M. (1990). Genetic and morphological variations in the Indian mackerel Rastrelliger kanagurta (Cuvier 1817) from the Goa region. Proc. Indian Acad. Sci., 99(6), 457-465.

Menezes, M. R., Naik, S., \& Martins, M. (1993). Genetic divergence in the Indian Mackerel Rastrelliger kanagurta (Cuv) from the coastal waters of Peninsular India and the Andaman Sea. Indian Journal of Fisheries, 40(3). 135-141.

Miller, M. P. (1997). Tools for Population Genetic Analysis (TFPGA). Version 1.3. Department of Biological Sciences, Northern Arizona University, Flagstaff.

Moria, S. B., Haryanti, H., Permana, G. N., \& Slamet, B. (2006). Karakteristik genetik dan struktur populasi ikan 
napoleon, Cheilinus undulates di Perairan Indonesia. Jurnal Riset Akuakultur. 1(3), 315-323.

Nei, M. \& Tajima, F. (1981). DNA polymorphism detectable by restriction endonucleases. Genetics. 97, 145- 163 .

Nishida, T., Chow, S., \& Grewe, P. (1998). Review and research plan on the stock sructure of yellowfin tuna (Thunnus albacares) and bigeye tuna (Thunnus obesus) in the Indian Ocean. Proceedings Indian Ocean Tuna Commission, Victoria, Seychelles. 9-14 November 1998.

Reynolds, J., Weir, B. S., \& Cockerham, C. C. (1983). Estimation of the coancestry coefficient: basis for a short-term genetic distance. Genetics, 105(3), 767-779.

Santos, M. D., Lopez, G. V., \& Baru, N. C. (2010). A pilot study on the genetic variation of eastern little tuna (Euthynnus affinis) in Southeast Asia. Philippine J. of Sci. 139(1), 43-50.

Sukumaran, S., Sebastian, W., \& Gopalakrishnan, A. (2017). Genetic population structure and historic demography of Indian mackerel, Rastrelliger kanagurta from Indian peninsular waters. Fisheries Research, 191. 1-9.

Suwarso, S. \& Zamroni, A. (2014). Analisis struktur populasi tiga spesies layang (Decapterus spp.) di Laut Jawa dan sekitar Sulawesi: Saran Pengelolaan Berkelanjutan Ikan Pelagis Kecil dan Evaluasi WPP. Jurnal Kebijakan Perikanan Indonesia, 6(2), 75 - 86.

Tabata, K. H., Kishioka, M., Takagi, A., Mizuta, N., \& Taniguchi, T. (1997). Genetic diversity of five strains of red sea bream Pagrus major by RFLP analysis of the mtDNA D-Loop region. Journal Fisheries Science. 63(3), 344-348.

Willette, D. A., Santos, M. S. \& Leadbitter, D. (2016). Longtail tuna Thunnus tonggol (Bleeker, 1851) shows genetic partitioning across, but not within, basins of the Indo-Paciûc based on mitochondrial DNA. Journal of Applied Ichthyology. 32, 318-323.

Wilson, D. S., \& Clarke, A. B. (1996). The shy and the bold. Natural History. 9/96, 26-28.

Wright, S. (1951). The genetical structure of populations. Annals of Eugenics. 15(4), 323-354.

Wyrtki, K. (1961). Physical oceanography of the Southeast Asian Water. NAGA Report, Scripps Inst. Oceanography. The University of California, La Jolla, California. 2.

Zamroni, A., Suwarso, S., \& Nugroho, E. (2014). Struktur genetika populasi ikan malalugis biru (Decapterus macarellus Cuvier, 1833) Di Sekitar Sulawesi Berdasarkan Mt-DNA Marker. J. Lit. Perik. Ind. 20(1), 31-34.

Zamroni, A., Suwarso, S. \& Mardlijah, S. (2016). Genetika populasi Rastrelliger kanagurta Di Perairan Barat Sumatera, Selat Malaka Dan Laut Cina Selatan. J. Lit. Perik. Ind., 22(1), 1-8.

Zein, M. S. A. (2007). Keragaman daerah kontrol DNA Mitokondria Rusa Timor (Cervus timorensis timorensis) di Pulau Timor, Alor dan Pantar. Biota, 12(3), 138-144. 